\title{
PERCEPTION OF POST PARTUM MOTHERS WITH SECTIO \\ CAESAREA ON THE ROLE OF THE MATERNITY NURSE AT \\ KARTIKA HUSADA HOSPITAL PONTIANAK, WEST BORNEO
}

\author{
Dwi Kurniasih, Elly Marce Titihalawa, Florida Listavia Panggus
}

Midwifery Academy of Dharma Insan, Pontianak, West Borneo

\begin{abstract}
Background: The risk of morbidity and mortality in the postpartum period often occurs due to delays in handling and lack of knowledge. Maternity nurse has an important role in improving women's health status while still paying attention to the concept of family centered maternity care. This study aimed to explore what nurses need to do based on the patient's perception.

Subjects and Method: This was a qualitative study with phenomenology approach conducted at Kartika Husada Hospital, Pontianak, West Borneo, in March 2021. A sample of 8 study subjects was selected consisting of 5 key informants of post-partum mothers and 3 triangulation informants of nurses, including the head nurse of the team and the head of the room. The data were collected by semi-structured interviews and analyzed by content analysis.

Results: Three major themes of the role of maternity nurses were identified based on the perception of postpartum mothers with sectio caesarea in hospitals as follows: (1) Nurses acting as care providers; (2) Educators; and (3) Advocators. Those roles were carried out both for postpartum mothers and their families during hospitalization with the concept of family centered maternity care.

Conclusion: Maternity nurses based on the perception of postpartum mothers with sectio caesarea act as care providers, educators, and advocates for patients and families.
\end{abstract}

Keywords: maternity, post-partum, sectio caesarea, nurse

\section{Correspondence:}

Dwi Kurniasih. Midwifery Academy of Dharma Insan, Pontianak, West Borneo. Jl. Hasanuddin 115C, Pontianak, West Borneo. Email: dwi.kurniasih@akperdharmainsan.ac.id. Mobile: +6281351607978 . 